\title{
11. TRADITIONAL AND INNOVATIVE METHODS IN APPROACHING MUSIC STYLES. PEDAGOGICAL IMPLICATIONS
}

\section{Loredana Viorica Iațeșen ${ }^{111}$}

\begin{abstract}
The approach to music styles entails an in-depth musicological analysis aimed at synthesizing numerous bibliographical sources belonging to different fields and directions of research. A chronological overview of studies (Jean Molino, Fait musical et sémiologie de la musique, 1975; Jean Jaques Nattiez, Quelques reflexions du style, 1993; R. J. Pascall, Style, in The New Grove Dictionary of Music and Musicians, 1994; Jean Jaques Nattiez, La musique de l'avenir, in Musique. Une Encyclopédie pour le XXI siècle, 2003; Mario Baroni, Stil şi mutaţii stilistice în tradiţia muzicală europeană, in Musique Une encyclopédie pour le XXI siècle, 2006) and of universal (Leonard Meyer, Explaining Music, 1973; Charles Rosen, Le style classique: Haydn. Mozart, Beethoven, 1978; Leonard B. Meyer, Style and Music. Theory, History and Ideology, 1989; and Romanian specialised literature (Cornel Ţăranu, Elemente de stilistică muzicală (sec. XX), 1981; Edgar Papu, Despre stiluri, 1986; Valentina Sandu-Dediu, Alegeri Atitudini Afecte, 2010; Vasile Iliuţ, O carte a stilurilor muzicale, 2011; Valentin Timaru, Stilistică muzicală, 2014) from the late $20^{\text {th }}$ century and the beginning of the $21^{\text {st }}$ century, reveal the different and, more often than not, contrasting views of historians, analysts, aestheticians, philosophers, scholars and educators, starting from the meaning of the very idea of style, to the reception of this phenomenon in contemporaneity. On these grounds, this study proposes a systematization of the most relevant landmarks in documentation to date, for the purpose of applying them from a didactic perspective.
\end{abstract}

Key words: history, style, genre, language, message

\section{General considerations on style}

The reflection on musical styles from a pedagogical perspective clearly involves the confrontation between various sources on the conceptualization of this phenomenon, as regards the manner in which the latter was delineated in articles easily accessible to young researchers. For example, on the page dedicated to the general presentation of the discipline in question, Wikipedia provides the following definition: "Stylistics is the discipline that studies style and is applied in art in general, or in one of its branches in particular". ${ }^{112}$ In turn, in his article published in Dicţionarul de termeni muzicali (Dictionary of Musical Terms), the musicologist Alexandru Leahu views style as an "aesthetic category defined by the creations of a culture, an era, a group of creators or an artist, representative by adopting structural solutions or configurations"113.

By comparing these two possible definitions or conceptualizations of the phenomenon, the complexity of the discipline, the features of which derive not only from an artistic perspective, but also from its relation to the other fields of knowledge, becomes indisputable. To return to the article mentioned in the Dictionary of Musical Terms, the researcher draws attention to Lucian Blaga's

\footnotetext{
111 Associate Professor PhD, "George Enescu" University of Arts from Iaşi of Romania, email: iatesenloredana@yahoo.com

112 https://ro.wikipedia.org/wiki/Stilistică_muzicală

113 Alexandru Leahu, art. Stil, in: Dicţionar de termeni muzicali, Editura Enciclopedică, Bucureşti, 2008, p. 524
} 
opinion, brought forth in the study Orizont şi stil in Trilogia culturii (Horizon and Style in the Trilogy of Culture), on the relation between this concept and contradictions of a philosophical, psychological and general-cultural nature in the development of historical stages: "in their temporal sequence, styles also have a historical dialectic, just like the cultural periods the expressions of which they are, thereby betraying their anaesthetic origin" 114 .

\section{Approaching the discipline Musical Stylistics from the perspective of research}

Based on the general considerations of the term, this study proposes a didactic approach to style from the perspective of the most relevant theories and publications that have appeared throughout the ages. In this regard, the relation between style and rhetoric is important in understanding the discipline, starting from the conceptions of some of the ancient philosophers. In Aristotle's vision, the eloquence of discourse depends on the manner in which it is exposed. This is one of the defining characteristics of rhetoric as regards the art of oral persuasion, or the purpose of the message, establishing three phases of style (plain, humilis; medium, mediocrus; grand, grans). This particularization was also applied in the classification of literary genres until the Middle Ages (according to the tragic or comic styles) ${ }^{115}$.

As regards sound, the reflection on the international models produces by the various cultures - oriental maqamat, ancient Greek hymns and other monodies (Delphic Hymn, Seikilos Skolion Epitaph), Byzantine modes, Gregorian sequences, medieval secular songs - entails not only the analysis of linguistic parameters (i.e. the belonging to various modal structures, the establishment of rhythm categories), but also the knowledge and understanding of the ethos, religious and historic conceptions of various civilizations, attempting all the while to establish the importance of music within other disciplines and fields of activity.

In the evolution of the ancient musical eras, more precisely in Ars Antiqua, through the two creators, Leonin and Perotin (promoters of incipient polyphonic genre and works), one of the representatives of medieval secular music, Adam de la Halle and, most importantly, Guillaume de Machaut (La Messe de Notre Dame $)$ in the $14^{\text {th }}$ century, the increasing importance given to compositional techniques, language processes and, especially, to the role of the creator in the artistic and intellectual society of the era, as author of full works, belonging to secular or religious genres, is emphasized. Only a few aspects have determined Alexandru Leahu to comment on the fact that style could derive from that "maniera di comporre" ${ }^{116}$, an idea taken over from Le Institutione harmoniche, Gioseffo Zarlino's Treaty which appeared in 1558 . In the $17^{\text {th }}$ century, the transposition of the theory of emotions in musical practice, an issue debated by

\footnotetext{
${ }^{114}$ Alexandru Leahu, op. cit. p. 525

115 Mario Baroni, Style et mutations stylistiques dans la tradition musicale européenne (Style and stylistical mutations in European music tradition), in: Histoires des musiques européennes sous la direction de JeanJacques Nattiez, vol IV, Actes Sud, 2006, pour la traduction français, p. 53

${ }^{116}$ Alexandru Leahu, art. Stil...op. cit, p. 525
} 
researchers H. Unger ${ }^{117}$, Valentina Sandu-Dediu ${ }^{118}$ or Mario Baroni, refers to the relevance of styles based on Atanasius Kircher's vision in the Musurgia Universalis treaty (1650), with the following cataloguing: "ecclesiasticus, canonicus, moteticus, madrigalescus, phantasticus, melismaticus, choraicus,

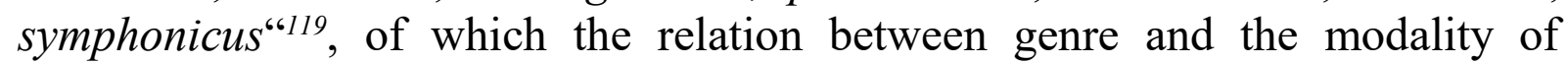
rendering it in the writings of the time are of particular importance.

With regard to the art of sound, the beginning of the $18^{\text {th }}$ century stands out through the creators' attitude, through their critical position to meditate or to combat the relation between old and new, between tradition and modernity. The polemic reassessing the notion of "modernity" surfaces once with the incisive text of the composer Giovanni Artusi on Claudio Monteverdi's creation ${ }^{120}$. Giulio Cesare Monteverdi's (Claudio Monteverdi's brother) answer focused on explaining the famous binomial musica vecchia - musica moderna that crossed eras under different meanings.

In the $17^{\text {th }}$ and $18^{\text {th }}$ centuries, once with the new theories according to which art is related to the writings on literature and philosophy of the time, the concept of style acquires more and more particular nuances, depending on the views of the authors. It is the moment when rhetoric is gradually replaced by a new aesthetic direction, based on which the meaning of a work of art, in general, or of a musical composition, in particular, is increasingly directed towards emphasizing subjectivity.

Mario Baroni, in the study Styles et mutations stylistiques, draws attention to some significant published works (1788, Karl Philipp Moritz's treaty Über die bildende Nachahmung des Schönen - On the Formative Imitation of Beauty, followed in 1789 by another significant work for the theory of plastic arts, Goethe's treaty, Einfache der Nachahmung Natur, Manier, Stil - Simple Imitation of Nature, Manner, Style) in the research of the time, stressing the idea of revealing a work of art as an imitation of nature or as a manifestation of the author's individuality, concentrating on completing his/her artistic product right down to the smallest detail. Furthermore, the individual dimension of style is captured by the French writer Georges Louis Buffon in the traditional formulation of "Le style c'est l'homme" - Style is the man.

The correspondence of these ideas in the stylistic approach of the creators from the Viennese musical Classicism is thus understood. Their works, though characterized by common expression and language, sounds recognizable in the sphere of aesthetics and within the general style of the era, the particular treatment of the opuses of Joseph Haydn, Wolfgang Amadeus Mozart, Ludwig

\footnotetext{
${ }^{117}$ H. H. Unger, Die Beziebungen zwischen Musik und Retorik im 16-18, Jahrhundert, Würtzburg, Triltsch, 1941, apud. Mario Baroni, Style et mutations stylistiques dans la tradition musicale européenne (Style and stylistical mutations in European music tradition), in: Histoires des musiques européennes sous la direction de JeanJacques Nattiez, vol IV, Actes Sud, 2006, pour la traduction française, p. 54

118 Valentina Sandu-Dediu, Alegeri, Atitudini, Afecte, Despre stil şi retorică în muzică, Editura Didactică şi Pedagogică, Bucureşti, 2010

119 Alexandru Leahu, op. cit. p. 525

120 "L'Artusi overo della imperfectione della moderna musica", in Claude V. Palisca. "Prima pratica", Grove Music Online, ed. L. Macy
} 
van Beethoven, imply a distinct perception on each and every creative universe. Moreover, according to the innovative conceptions revealed by linguistic research conducted through the appearance of Charles Bally's treaty ${ }^{121}$, according to which "styles generate choices operated by speakers or deviations which the speakers introduce in relation to the dominant stylistic norm" following Jean Molino ${ }^{123}$, Charles Rosen ${ }^{124}$, Leonard B. Meyer ${ }^{125}$, Valentina Sandu-Dediu's research in music, sound structure analysis, interpretation of stylistic formations or style stratification, creations of classical composers and not only, have been reassessed, an issue to which we shall return later.

Mario Baroni, in the study above-mentioned, warns about the innovative conceptions of the $19^{\text {th }}$ century, a period in which rhetoric, seen as a method of research of stylistic phenomena, is replaced by the importance given to literary research, culminating in the vision of authors such as Benedetto Croce or Karl Vossler and especially about the theories and methods which Leo Spitzer proposed at the beginning of the last century ${ }^{126}$. By cumulating and summarising linguistic, literary, psychological and philosophical theories from the late $19^{\text {th }}$ century and early $20^{\text {th }}$ centuries, one becomes aware of the fact that the distancing of authors and composers from the reference subject, in relation to the mentality, aesthetics and language of the era, determines particular psychological states which, in turn, can gradually make up a system ${ }^{127}$.

The examples of musical literature of the $19^{\text {th }}$ century are numerous given the fact that the very condition of the creator in the century of nations is special. Musicians such as Robert Schumann, Hector Berlioz, Franz Liszt, Richard Wagner, Gustav Mahler, prolific personalities who stood out in many hypostases, i.e. composers, conductors, performers, music critics, etc., are only a few such examples. Moreover, by means of their opuses, they themselves succeeded in emphasizing their theoretical conceptions, published or not, yet embedded in their compositions. For instance, Schumann's unique combination of literary and musical activities resulted in a particular genre, a programmatic miniature, a species which, in turn, pays special attention to the potential correspondences between sound and extra-musical indications. Furthermore, Franz Liszt, who had the temper of a volcanic creator, himself a pianist, critic, animator of musical life, introduced the programmatic symphonic poem, a genre that can be interpreted as a result of the creator's innovative conception across several parameters: musical, literary, historical, psychological, etc.

\footnotetext{
${ }^{121}$ Traité de stylistique française, Winter, Heidelberg, 1909

122 Mario Baroni, Style et mutations stylistiques dans la tradition musicale européenne (Style and stylistical mutations in European music tradition), in: Histoires des musiques européennes sous la direction de JeanJacques Nattiez, vol IV, Actes Sud, 2006, pour la traduction française, p. 55

${ }^{123}$ Jean Molino, Fait musical et sémiologie de la musique, Musique en jeu, nr. 17, pp. 37-62,1975, apud. Mario Baroni, op. cit., p. 69

${ }^{124}$ Charles Rosen, Le style classique: Haydn. Mozart, Beethoven, Paris, Gallimard, 1978

${ }^{125}$ Leonard B. Meyer, Style and Music. Theory, History and Ideology, Philadelphie, University of Pennsylvania Press, 1989

${ }^{126}$ Mario Baroni, op cit., p. 54

${ }^{127}$ Leo Spitzer in Linguistics and Literary History, Princeton, Princeton University Press, 1948 and in other publications inserted in the research in linguistics, the idea of detecting stylistic features from the perspective of the author's psychology.
} 
Without a shadow of a doubt, among the creators above-mentioned, the culmination was reached by Richard Wagner's complex personality. He was an author of synthesis and innovation, in whose case human ambition, literary and philosophical culture, talent for musical composition, libretto writing and stage design, responsiveness to contemporary musicians and not only (we are referring here to the support offered for completing the theatre at Bayreuth, the quintessence of his wide-scale scenic concerns and conceptions) all came together in a highly constructive manner.

The styles of such authors entail a comprehensive undertaking, aiming at revealing connections from various fields, research related to historical mentality, to the social, psychological and philosophical dimensions of the time, all of which must be indisputably reassessed in the context of the latest discoveries in the field. The critical opinion about the period, the creator, the work and the interpretation to which the above are subject, is, therefore, required.

These are only a few issues that will be further discussed in the hermeneutics exegesis of the $20^{\text {th }}$ century. It was then that the idea according to which the receiver, interested in establishing a certain style, certain features, entailing the need to overcome an objective reality in view of interpreting the phenomenon (we refer here to the concreteness of data, of possible languages used to decrypt the message of literary or musical works, or that of fine arts), given the fact that "identity features are not the fruit of perception, but of interpretation"128, was increasingly imposed.

This theory can be applied to many musical opuses. A highly relevant example in this regard is Wozzeck, the first opera by Alban Berg, a masterpiece of $20^{\text {th }}$ century, a score in which, although composed in a sound synthesis language - tonal-modal-serial-dodecaphonic - more difficult to access immediately, the rigor arises from the very orderly organization of structure, imposed by the creator himself. There is, therefore, an interesting relation between what one listen to as a receiver-spectator and what one reads in the score, as a receiver-analyst.

What is certain is that the complex message of the work can be understood only partially by a melomaniac listener (taking into account, all the while, the social component of the libretto and the tension derived from the relation between music and text at a general level). All the details related to music, to the construction of the score, to the correspondence between the dramaturgy of text and that of sound, require additional explanations and interpretations, semantic comments, the perception and decoding of style or, more precisely, of stylistic complexity, are the responsibility of the musicologist.

If the identification of the style particular to an era, a historical period, a phase in a composer's creation, most often entails an interdisciplinary approach,

\footnotetext{
128 "Les traits d'identité ne sont pas le fruit de la perception, mais de l'interprétation", op. cit. Mario Baroni, Style et mutations stylistiques dans la tradition musicale européenne, p. 57
} 
establishing the stylistic features of an opus is a challenge for both researcher and academic. In this regard, the literature warns about certain references. For instance, the work of the musicologist Valentina Sandu-Dediu, Alegeri, Atitudini, Afecte Despre stil şi retorică în muzică (Choices, Attitudes, Affection on Style and Rhetoric in Music) discusses the methods of stylistic analysis proposed by Jan La Rue ${ }^{229}$ back in 1970, a treaty focused on identifying the particularities of sound language (melody, rhythm, harmony, orchestration) was completed several years later by Leonard B. Meyer ${ }^{130}$, Mario Baroni ${ }^{131}$.

The views on the discovery and interpretation of this phenomenon in the $20^{\text {th }}$ century reveal that the theories of Jean Pierre Bartoli ${ }^{132}$, Jean Molino ${ }^{133}$, JeanJaques Nattiez ${ }^{134}$ and Valentina Sandu-Dediu validate one of the ideas that Mario Baroni synthesized in his study on the identification of style from the perspective of two complementary aspects. Such a position is, in fact, no more, no less than resuming the conception of the linguist Charles Bally, stated as far back as 1909, in Traité de stilistique française, on the analysis of style as a choice or as a deviation.

The research by means of which style reveals itself as a consequence of choices can undoubtedly be applied to a variety of pieces of music, from various eras. Given the fact that this phenomenon is in close dependence with the possible receptors, all of the musicologists above-named can evidently interpret some nuances of the phenomenon in a different manner, based on their culture, sensitivity, and, why not, their attachment, declared or not, to a given era, historical period, creator or work. In any case, the approach to styles from a didactic perspective first and foremost regards the detection of the styles specific to historical periods, musical cultures or subcultures, composers, etc.

The comments target language peculiarities in relation to the reference opus. The research approach can subsequently focus on details, stylistic comparisons between various eras, between the opus characteristic of a certain historical period, the sound, language, ethos of which can reiterate in various composition techniques in another era, etc. In what follows, both traditional and innovative techniques will be systematized in treating musical styles, starting from the criteria provided by the musicologist Oleg Garaz in his study Fenomenul compresiei stilistice în muzica europeană (The phenomenon of stylistic compression in European music), published in two of the issues of the journal Muzica (Music) no. 2/ 2013 and no. 3/ 2013 and by Mario Baroni in his

\footnotetext{
${ }^{129}$ Jan La Rue, Guidelines for Style Analysis, W.W. Norton \& Co, New York, 1970

${ }^{130}$ Leonard B. Meyer, Explaining Music, Berkley, University of California Press, 1973; Style and Music. Theory, History and Ideology, Philadelphia, University of Pennsylvania Press

${ }^{131}$ Mario Baroni, op. cit. p. 60

132 Jean Pierre Bartoli, La Notion de style et l'analyse musicale : bilan et essai d'interprétation, in : Analyse musicale 17 (octobre 1989), pp. 11-14; La musicologie, la stylistique et le concept de style, in : Musique et style, Méthodes et concepts, séminaire post-doctoral interdisciplinaire, Paris, Université de Paris-Sorbonne, Observatoire musical français, 1995, pp. 29-35.

${ }^{133} \mathrm{Jean}$ Molino, Le singe musicien. Sémiologie et anthropologie de la musique. Précédé de : Introduction à l'œuvre musicologique de Jean Molino par Jean-Jacques Nattiez Paris : Actes Sud / INA, 2009

${ }^{134}$ Jean Jaques Nattiez, Musicologie générale et sémiologie, Christian Bourgois, Paris, 1987
} 
study Stil şi mutaţii stilistice în tradiţia muzicală europeană (Style and stylistic mutations in European musical tradition).

\section{Traditional means of approaching musical styles}

Style can be understood in relation to the method of teaching the discipline of music history, more specifically, based on historical criteria ${ }^{135}$, the succession of eras: Antiquity, the Middle Ages, Renaissance, Baroque, Classicism, Romanticism, Impressionism, Expressionism, Neoclassicism, etc. The thorough analysis of the phenomenon reveals the criterion of period phasing ${ }^{136}$, through the fragmentation of a creator's style in two, three or more layers, depending on the composer's belonging to a culture, moments of technical or expressive accumulation in creating his style. The model of approaching style based on national and geographic ${ }^{137}$ criteria was usually created as a branch of a more general style, by particularizing some features in relation to moments in which a given culture, a generation of creators, linguistic particularities and their opuses reached their peak: the style of the School of Notre Dame ${ }^{138}$, the culmination of linguistic features or genres, of the creators from Ars Antiqua, the style of the Franco-Flemish School, the style of the Russian National School, the style of Schola Cantorum, etc.

Another perception of style which complies with G. L. Buffon's idea that Style is the man refers to the totality of features that reflect the image of a composer's creation. This idea that can be applied in greater detail by phasing the composer's creation according to the linguistic particularities of his opuses, and to the relevant moments in the development of his artistic career, etc. The relation between style and genre is materialized by interweaving the two concepts in the famous phrases: "chamber style", "symphonic style", vocalsymphonic style, "concerto style", "operatic style"139. In this regard, certain models established in the history of music, styles, creators and opuses come into prominence, developing classifications such as: the chamber style in the last quartets by Beethoven; the unmistakable operatic style of Giuseppe Verdi's scenic opuses, etc.

Interrelations can be equally established between style-genre-language as regards the vocal style of Hector Berlioz's symphonic creation, the instrumental style of Mozart's works, the chamber style in Fr. Chopin's accompaniment for concerts for piano and orchestra, the symphonic style of J. Brahms's chamber music, etc. The detection of style in relation to various techniques of writing, language, sound system, genre, vocal or instrumental character of the piece, starting from the development of an analytical scheme based on each such parameter, a research inaugurated by Jean la Rue and continued by other musicologists in the Romanian and universal perimeter, can be applied in the approach to any musical composition.

\footnotetext{
${ }^{135}$ Oleg Garaz, Fenomenul compresiei stilistice in muzica europeană, in: Revista Muzica nr. 2, Editura Uniunii Compozitorilor şi Muzicologilor din România, 2013, p.47

${ }^{136}$ Ibidem

${ }^{137}$ Idem, op. cit, p. 48

${ }^{138}$ Ibidem

${ }^{139}$ Ibidem
} 


\section{Innovative means of approaching musical styles}

The innovative processes of style identification from the perspective of the researchers of the second half of the $20^{\text {th }}$ century include:

4.1. The musical style of the eras, historical periods and creation stages is most often the result of syntheses, associations and overlays of historical, political, linguistic, psychological, philosophical, aesthetic, cultural and artistic influences. This enumeration of a plurality of features reveals the fact that the approach to musical stylistics is achieved by improving and applying knowledge acquired from various fields.

4.2. In general terms, style is a choice or a deviation from norms, a traditional process that can become innovative by relating features, by synthesising them, depending on the object of reference (period, music culture, compositional creation, chamber, concert, symphonic, vocal-symphonic, operatic opuses, etc.).

The first reference imposed at musical level concerns the Renaissance creation, in which Giovanni Pierluigi da Palestrina's style is best known in the academic area, a creator also included in the conventions of the era, whose sound discourse construction principles have been transposed in the academic sphere. In Palestrina's case, style is a choice of the language of an era, the conventional character of which is assimilated and accentuated by the composer in other to configure a purity of style. Apart from the particular features derived from the Renaissance creators' belonging to various schools (Italian, German, English, French) or the particularities according to language and expression specificities of each representative who chooses to exploit various issues related to the era, in the musical revival as a whole, Gesualdo da Venosa's creation stands out, as a deviation from the conventions of the era. The characteristic predominance of chromatic, melodic and harmonic innovations, tension modulations achieved step by step, set the creator, whose visionary thinking anticipated musical modernism, in the top of the pyramid.

The interpretation of style as a choice makes a particular case. This hypostasis regards synthesising elements from the same period, found in major or minor composers: intonations, writing techniques, genres, forms. It is the case of G. F. Haendel, whose compositional style reflects the synthesis of Italian, French, German or English features of the creators from the Baroque period. In the same period, the unity of style in the creation of a composer, an idea set forth by the musicologist Oleg Garaz on "Johann Sebastian Bach's monolithic style" 140 clearly manifested throughout his creative evolution, is highlighted.

In the context of musical Classicism, the historical tradition proclaims the famous triad Haydn-Mozart-Beethoven, in whose works, although included in terms of chronology, genre and general language in the general category of the Classical style, many deviations can be noticed by particularizing opuses. In adding the finishing touches to the quartet and symphony genres, Joseph Haydn went through many moments of style accumulation. Thus, his reception is more

\footnotetext{
${ }^{140}$ Oleg Garaz, Fenomenul compresiei stilistice în muzica europeană, in: Revista Muzica nr. 3, Editura Uniunii Compozitorilor şi Muzicologilor din România, Bucureşti, 2013, p. 55
} 
that of a synthesiser between Baroque and Classicism. Wolfgang Amadeus Mozart, on the other hand, by transferring vocality in instrumentality, by the harmonic novelty of works such as Don Giovanni or symphonies (Symphony No. 40, Symphony No. 41), by melodic and rhythmic fantasy from the composition of discourse, by the diversity in treating the scenic genre, represents the Classic creator in a synthesis of the elements of the period as a whole.

Ludwig van Beethoven detaches as a deviation from the classical style, by innovative features of language, by a different rhetoric from that of the Classics, by the tumult of an indubitably Romantic expression. As a result, phasing his creation according to chronology, genre and, especially, biographical criteria, becomes inefficient in commenting on style. By means of the technical, linguistic and theatrical novelties which his creation brings, it can be interpreted as visionary in the context of musical Classicism, as a first phase of Romanticism and even of Modernity in relation to tradition. At first sight, early Romantic creations appear to be unitary in terms of a general historical and stylistic development, given the common relationing with Beethoven's opuses and, especially, the comparison with late Romanticism, ground-breaking through the novelties proposed by the majority of the creators.

A closer look, however, captures the synthesis creation of Baroque and Classicism in the discrete Romanticism of Schubert's symphonies, or the novelty of structural segmentations and specific expression of Schumann's symphonies and, especially, the remarkably difficult harmonic innovations of Chopin's opuses. Those classifications of the Romantic period, according to the composers' biography and the preponderance of capitalizing on miniature, concerto or symphonic genres are only relevant insofar as a concentrated historical presentation is concerned which, however, is stylistically irrelevant.

Another reference in line with expression and language modernity, aimed, on the one hand, at consolidating the Romantic style and, on the other hand, at preparing a broad spectrum of stylistic choices and deviations of the $20^{\text {th }}$ century, was established through the contribution of Franz Liszt and Richard Wagner, both of which are representatives of new directions in the evolution of genres (symphonic poem and opera), language (extended tonality), in amplifying expression until it reaches its peak: the post-romantic traditional style and the German Expressionist innovative style. There is no doubt that the academic approach to style encounters most obstacles in the comment on styles particular to the $20^{\text {th }}$ century. This is due to the parallel development of styles in a concentrated temporal context.

Impressionism stands in contrast as regards geographic location, musical culture, mentality and expression. Even if, at the level of ideas and general sound, it is meant to be a rejection of tradition, this innovative style includes many references of old music and Romantic expression. We refer to certain sources of creative inspiration, in the case of Claude Debussy and Maurice Ravel, or variation, motivic or orchestral transformation techniques. As regards the didactic approach to style in the second half of the $20^{\text {th }}$ century, one of the processes, namely the identification of the phenomena as synthesis/antithesis, as 
association or overlap of musical and cultural particularities from earlier eras, as it is revealed in Luciano Berio's Sinfonia (Symphony) for eight amplified voices and orchestra, a highly complex opus that highlights quotations from the personal creation of the Italian composer and from the works of other representatives belonging to various movements, periods, schools, cultures, languages, styles in the history of music: J. S. Bach, J. Brahms, H. Berlioz, Claude Debussy, M. Ravel, A. Schönberg, R. Strauss, I. Stravinski, P. Boulez.

\section{Conclusions}

The stylistic approach to any of the opuses mentioned, and not only, takes into account more than just the application of specialized theories. The relationship and connection with other fields entail possessing knowledge of an entire process of a given creation, in relation to the mentality and psychology of the era.

Even though every musical composition is unique, its approach from a complex perspective reveals it as the product of a society. The process of stylistic identification entails the acceptance of conventions specific to a given era, of traditional classification methods which stand out, in relation to one another, through the very nature of the development of historical, social, political, cultural events, which can be reassessed according to the various opinions of researchers.

The difficulty arises especially in detecting such deviations from a certain convention (era, period, a composer's creation) because, as Mario Baroni commented, "the process of mutation follows an extremely intricate itinerary of dialectical relations between the rules of language, the public's expectations, the problems of collective identity and the composers' personal identity, systems of social value that support it, the manners in which society judges these systems of values, and finally, the role of the composers who express them" ${ }^{\prime 141}$.

\section{References}

1. Bally, C. (1909/1921). Traité de stylistique française, Heidelberg

2. Baroni, M. (2006). Style et mutations stylistiques dans la tradition musicale européenne. In Jean-Jacques Nattiez (ed.) Histoires des musiques européennes, vol IV, (pp. 53-70), Actes Sud

3. Bartoli, J. P. (1989). La Notion de style et l'analyse musicale: bilan et essai d'interprétation. Analyse musicale 17, pp. 11-14

4. Bartoli, J. P. (1995). La musicologie, la stylistique et le concept de style. In Musique et style, Méthodes et concepts, séminaire post-doctoral

\footnotetext{
141 “..le processus de mutations suivent un itinéraire extrêmement intriqué de relations dialectiques entre les règles du language...les attentes du publique, les problèmes d'identité collective et d'identité personnelle des compositeurs, les systèmes des valeurs sociales qu'il soutiennent, les manières dont la societé juge ces systèmes des valeurs et, enfin, le rôle des compositeurs qui l'expriment", in : Mario Baroni, Style et mutations stylistiques dans la tradition musicale européenne (Style and stylistical mutations in European music tradition), in: Histoires des musiques européennes sous la direction de Jean-Jacques Nattiez, vol IV, Actes Sud, 2006, pour la traduction français, p. 67.
} 
interdisciplinaire, Paris, Université de Paris-Sorbonne, Observatoire musical français, pp. 29-35

5. Garaz, O. (2013). Fenomenul compresiei stilistice în muzica europeană. Muzica, 2, 12- 49

6. Garaz, O. (2013). Fenomenul compresiei stilistice în muzica europeană. Muzica, 3, 16-57

7. La Rue, J. (1970). Guidelines for Style Analysis. New York: W.W. Norton \& Co

8. Leahu, A. (2008). Stil. In Dicţionar de termeni muzicali, (pp. 524-525). București: Editura Enciclopedică

9. Meyer, L. B. (1973). ExplainingMusic. Berkley: University of California Press

10. Meyer, L. B. (1989). Style and Music. Theory, History and Ideology. Philadelphie, University of Pennsylvania Press

11. Molino, J. (1975). Fait musical et sémiologie de la musique. Musique en jeu, $17,37-62$

12. Molino, J. (2009). Le singe musicien. Sémiologie et anthropologie de la musique. Précédé de : Introduction à l'œuvre musicologique de Jean Molino par Jean-Jacques Nattiez Paris: Actes Sud / INA

13. Nattiez, J. J. (1987). Musicologie générale et semiology. Paris: Christian Bourgois

14. Rosen, C. (1978). Le style classique: Haydn. Mozart, Beethoven. Paris: Gallimard

15. Sandu-Dediu, V. (2010). Alegeri, Atitudini, Afecte, Despre stil şi retorică în muzică. Bucureşti: Editura Didactică şi Pedagogică

16. Spitzer, L. (1948). Linguistics and Literary History. Princeton: Princeton University Press

17. Unger, H. H. (1941). Die Beziebungen zwischen Musik und Retorik im 1618, Jahrhundert, Würtzburg, Triltsch

18. https://ro.wikipedia.org/wiki/Stilistică_muzicală 